\title{
Non-OI Vibrio cholerae inguinal skin and soft tissue infection with bullous skin lesions in a patient with a penis squamous cell
} carcinoma

\author{
Aitziber Aguinaga*1, María E Portillo1, Jose R Yuste², Jose L del Pozo ${ }^{1,2}$, \\ Emilio García-Tutor ${ }^{3}$, Jose L Pérez-Gracia ${ }^{4}$ and José Leiva ${ }^{1}$
}

\begin{abstract}
Address: ${ }^{1}$ Department of Clinical Microbiology, University Hospital of Navarra, Pamplona, Spain, ${ }^{2}$ Infectious Diseases Division, University Hospital of Navarra, Pamplona, Spain, ${ }^{3}$ Department of Plastic and Reconstructive Surgery, University Hospital of Navarra, Pamplona, Spain and ${ }^{4}$ Department of Medical Oncology, University Hospital of Navarra, Pamplona, Spain

Email: Aitziber Aguinaga* - aaguinaga@unav.es; María E Portillo - meportillo@unav.es; Jose R Yuste - jryuste@unav.es; Jose L del Pozo - jlpozo@unav.es; Emilio García-Tutor - egtutor@unav.es; Jose L Pérez-Gracia - jlgracia@unav.es; José Leiva - jleiva@unav.es

* Corresponding author
\end{abstract}

Published: 19 May 2009

Annals of Clinical Microbiology and Antimicrobials 2009, 8:17 doi:10.1 I86/1476-07|I-8-17

This article is available from: http://www.ann-clinmicrob.com/content/8/I/I7

(c) 2009 Aguinaga et al; licensee BioMed Central Ltd.

This is an Open Access article distributed under the terms of the Creative Commons Attribution License (http://creativecommons.org/licenses/by/2.0), which permits unrestricted use, distribution, and reproduction in any medium, provided the original work is properly cited.
Received: 29 January 2009

Accepted: 19 May 2009

\begin{abstract}
Vibrio spp. is a pathogen rarely isolated in cancer patients, and in most cases it is associated with haematological diseases. Cutaneous manifestations of this organism are even rarer. We report a case of Non-OI Vibrio cholerae inguinal skin and soft tissue infection presenting bullous skin lesions in a young type II diabetic patient with a penis squamous cell carcinoma having a seawater exposure history.
\end{abstract}

\section{Introduction}

Vibrio cholerae is mainly related to water sources [1]. Contaminated seawater exposure or contaminated seafood ingestion are frequently associated with diarrhoea and/or extraintestinal infections such as otitis media, skin and soft tissue infections (SSTI) and bacteremia $[1,2]$. Vibrio $s p p$. is a pathogen rarely isolated in cancer patients, and in most cases it is associated with haematological diseases. Although the clinical picture may have a wide range in Vibrio spp. SSTI, bullous lesions are almost exclusively associated with $V$. vulnificus infection $[3,4]$ and have rarely been reported with non-O1 $V$. cholerae infections $[4,5]$.

We report here the case of a non-O1 $\mathrm{V}$. cholerae SSTI presenting bullous skin lesions in a diabetic patient with a solid tumour.

\section{Case report}

A 36-year-old patient from the Canary Islands (Spain) with controlled type II diabetes mellitus was diagnosed with a moderately differentiated squamous cell carcinoma of the penis in December 2006 in his local hospital. The patient underwent a partial penectomy. In the initial follow-up after surgery, the abdominal CT and granulation tissue were normal. The patient had been exposed to seawater and seafood from December 2006 to October 2007 when bullous skin lesions were observed in both inguinal regions during a examination. Lesions were fitted with inguinal metastases, and the patient underwent inguinal surgery followed by radiotherapy.

In November 2007 he was admitted to our hospital for a second consultation. Physical examination showed stink- 
ing lesions in both inguinal regions with cellulitis and bullae. Patient underwent an abdominal computed tomography (CT) scan with contrast that revealed the existence of several large necrotic adenopathies in the inguinal, scrotal and pubic areas (Figure 1). A right abdominal wall nodule and a left groin abscess extending from psoas muscle to skin were also observed. A CT scan of the chest showed pulmonary lesions compatible with metastases. Initial laboratory findings showed increased a white blood cell count of $20,3 \times 10^{9} / \mathrm{L}$ with $88,1 \%$ neutrophils, haemoglobin of $8,3 \mathrm{~g} / \mathrm{dL}$ and a C-reactive protein of $8,7 \mathrm{mg} / \mathrm{dL}$ (normal range $0-1 \mathrm{mg} / \mathrm{dL}$ ).

The patient was treated with a left inguinal region debridement, percutaneous drainage and flamazine therapy. Purulent fluid was obtained by swabbing from the fistulized left bulla and was sent for culture (Figure 2). At that time, two sets of blood cultures were drawn. Empiric intravenous antimicrobial therapy with ceftriaxone $1 \mathrm{~g} / 24$ $\mathrm{h}$ and metronidazole $500 \mathrm{mg} / 8 \mathrm{~h}$ was started. Daily cures with Flamazine were also indicated. A Gram stain of the sample showed abundant polymorphonuclear leukocytes, and cultures yielded Escherichia coli, Serratia marcescens and $V$. cholerae susceptible to the empiric antimicrobial therapy instituted. Blood cultures were sterile after incubation for six days. As the patient was not improving after 7 days of therapy, a new sample was taken with a syringe. Methicillin-susceptible Staphylococcus aureus and the same E. coli, characterized by phenotypic methods (biotype and antimicrobial susceptibility) were isolated. Those microorganisms were carbapenems-susceptible so the antibiotic therapy was switched to ertapenem $1 \mathrm{~g} / 24 \mathrm{~h}$ i.v. and cellulitis gradually improved.

A new sample was taken for control with a syringe from the left inguinal lesion after 2 weeks of treatment with

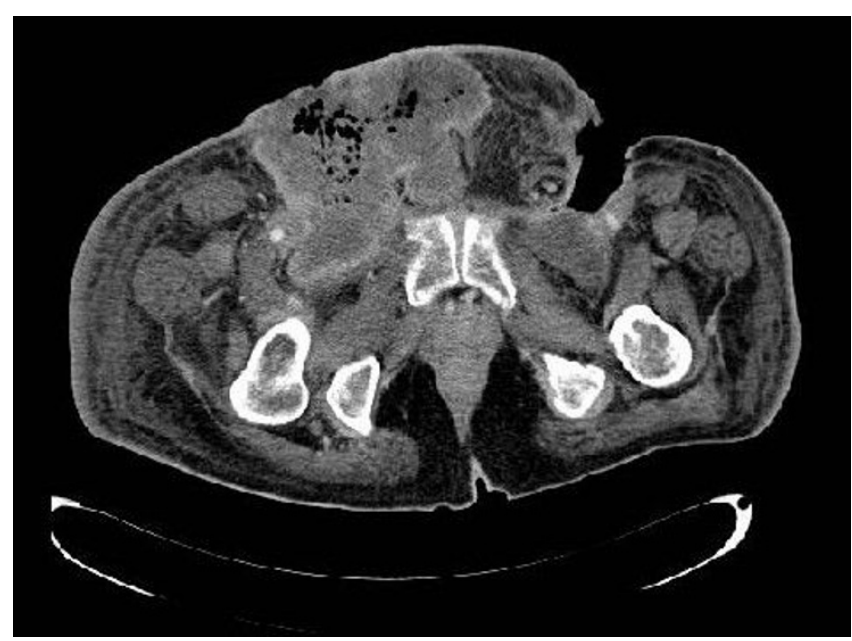

Figure I

Several large necrotic adenopathies in inguinal, scrotal and pubic area (CT scan).

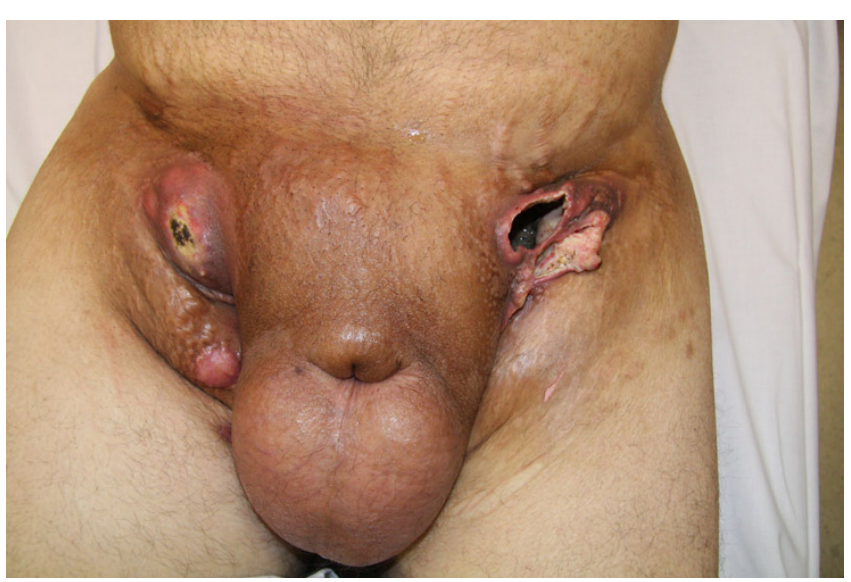

Figure 2

Skin lesions and cellulitis after a mayor cure.

ertapenem. Enriched alkaline peptone water $(1 \% \mathrm{NaCl}$ $\mathrm{pH}$ 8.5) and TCBS agar were added to the conventional media plates and only $V$. cholerae was again isolated. The therapy was changed to oral levofloxacin $500 \mathrm{mg} / 12 \mathrm{~h}$. After one month of treatment with levofloxacin a new sample for control from the left inguinal lesion was taken with a syringe, resulting sterile after incubation for a week in selective media. Thus, the levofloxacin dosage was switched to oral levofloxacin $500 \mathrm{mg} / 24 \mathrm{~h}$. After 40 days with levofloxacin $500 \mathrm{mg} / 24 \mathrm{~h}$, the right bulla fistulized, so a new debridement and percutaneous drainage was done in order to eliminate the necrotic tissue. New samples of both inguinal regions were obtained by means of syringe and were found sterile after 7 days of incubation in selective media.

During this time, the patient was treated with two cycles of first- and second-line palliative chemotherapy and one cycle of third-line palliative chemotherapy. Due to the metastasis progression, it was decided to stop the chemotherapy. In March, the patient returned to the Canary Islands under treatment with oral levofloxacin $500 \mathrm{mg} / 24$ h. The patient died two weeks later due to his underlying disease.

$V$. cholerae is a curved Gram-negative rod that grows as betahemolytic mucous colonies on blood agar plates and yellow colonies on thiosulfate-citrate-bile salts-sucrose (TCBS) agar plates. $V$. cholerae was identified by two commercial identification systems: VITEK 2 (bioMérieux ${ }^{\circledR}$ SA, Marcy-L'Etoile, France) and API 20E Enterobacteriaceae (bioMérieux ${ }^{\circledR}$, France). It was susceptible to the O/129 vibriostatic agent (Oxoid, Ltd., Basingstoke, UK), and slide agglutination tests with polyvalent antisera showed a nonO1, non-O139 serotype. Antibiotic susceptibility testing was performed by standard disk diffusion method on Mueller-Hinton agar, and minimal inhibition concentrations (MICs) were determined by the Etest ${ }^{\circledR}$ diffusion 
method (AB Biodisk ${ }^{\circledast}$, Solna, Sweden). According to CLSI guidelines interpretative criteria for Vibrio $s p p$. [6] the strain was susceptible to ampicillin $(8 \mu \mathrm{g} / \mathrm{ml})$, amoxicillin-clavulanic $(4 \mu \mathrm{g} / \mathrm{ml})$, ceftriaxone $(0.016 \mu \mathrm{g} / \mathrm{ml})$, ceftazidime $(0.25 \mu \mathrm{g} / \mathrm{ml})$, gentamicin $(1 \mu \mathrm{g} / \mathrm{ml})$, tobramycin $(4 \mu \mathrm{g} / \mathrm{ml})$, amikacin $(8 \mu \mathrm{g} / \mathrm{ml})$, ciprofloxacin $(0.004 \mu \mathrm{g} / \mathrm{ml})$, levofloxacin $(0.008 \mu \mathrm{g} / \mathrm{ml})$, piperacillin-tazobactam $(0.38 \mu \mathrm{g} /$ $\mathrm{ml})$, chloramphenicol $(8 \mu \mathrm{g} / \mathrm{ml})$, trimethoprim-sulfamethoxazole $(0.125 \mu \mathrm{g} / \mathrm{ml})$ and doxycycline $(2 \mu \mathrm{g} / \mathrm{ml})$. The sample was sent to the National Center for Microbiology (Majadahonda, Madrid, Spain) and was confirmed to be non-O1 $V$. cholerae non-producer of toxin. The gene sodB for the identification of $V$. cholerae was detected. Neither the genes $w b e \mathrm{O}$ and $r f b$ for the $\mathrm{O} 1$ and $\mathrm{O} 139$ serotype identification, nor the gene $\operatorname{ctxA}$ encoding cholera toxin were detected by multiplex PCR technique.

\section{Discussion}

SSTI are often deep and devastating [7]. Etiology may be mono or polymicrobial involving a mixed aerobe-anaerobe bacterial flora [7]. Although this case involved a necrotizing skin and soft-tissue infection with polymicrobial etiology repeated $V$. cholerae isolates suggested $V$. cholerae was likely a major player in this patient's infection.

Vibrio spp. SSTI may range from bullous skin lesions and localised cellulitis to severe necrotizing soft-tissue infection with secondary septicaemia $[8,9]$. V. vulnificus followed by $V$. parahaemolyticus and $V$. alginolyticus are the species most commonly isolated from wounds whereas
non-O1 $\mathrm{V}$. cholerae is the less common involved species $[3,10]$. Although bullous lesions occur mainly in patients with $V$. vulnificus, infection, bullae in non-O1 V. cholerae infection have been rarely reported $[4,5]$.

Vibrio spp. infections are rarely documented in cancer patients and they are infrequent in solid tumours [11]. Cellulitis due to non-O1 V. cholerae is rare and it is normally associated with the presence of chronic underlying diseases such as liver cirrhosis, diabetes mellitus, immunocompromised states or haematological malignancies such as chronic lymphocytic leukaemia, acute myeloid or lymphoblastic leukaemia and multiple myeloma or lymphocytic lymphoma $[2,4,5,11-17]$.

To the best of our knowledge, only 13 cases of non-O1 $\mathrm{V}$. cholerae extraintestinal infections in immunocompromised patients have been reported since 1978 (Table 1). Only one case had a documented cellulitis [12]. Patients were largely male ( 10 cases) with a mean age of 61 years (range, 36-78 years). Risk factors for Vibrio spp. infection were found in ten cases; 8 of them had liver disease. Interestingly, 10 patients had a solid tumour and only 3 patients had a hematological disease. Twelve cases presented fever, bacteremia or diarrhoea. Nine patients survived. The remaining patients died from $V$. cholerae infections or from underlying diseases. Our case is remarkable because it represents the second reported case of bullous lesions and cellulitis associated with non $\mathrm{O} 1-$ $V$. cholerae in a cancer patient.

Table I: Clinical summary of I 4 published cases of non-OI V. cholerae extraintestinal infections in immunocompromised patients.

\begin{tabular}{|c|c|c|c|c|c|}
\hline Age (years)/gender & Clinical syndrome & Risk factors other than neoplasia & Underlying condition & Outcome & Reference \\
\hline $72 / \mathrm{m}$ & $\begin{array}{c}\text { Fever } \\
\text { Bacteremia }\end{array}$ & Renal insufficiency & MM & Recovered & [13] \\
\hline $51 / \mathrm{m}$ & Pneumonia, diarrhoea & - & CLL & Expired & [14] \\
\hline $59 / \mathrm{m}$ & Bacteremia & Cirrhosis & Hepatoma & Recovered & {$[1]$} \\
\hline $69 / \mathrm{m}$ & Ascites & Cirrhosis & Hepatoma & Expired & [I] \\
\hline $50 / \mathrm{m}$ & Bacteremia & Cirrhosis & Hepatoma & Recovered & [I] \\
\hline $54 / \mathrm{m}$ & Bacteremia & Cirrhosis & Hepatoma & Recovered & {$[1]$} \\
\hline $60 / f$ & Diarrhoea & Cirrhosis & Hepatoma & Recovered & [15] \\
\hline $36 / \mathrm{m}$ & Bacteremia & Cirrhosis & Hepatoma & Expired & [15] \\
\hline $78 / \mathrm{m}$ & $\begin{array}{c}\text { Fever } \\
\text { Bacteremia }\end{array}$ & - & NSCLC & Recovered & {$[\mathrm{II}]$} \\
\hline $62 / \mathrm{m}$ & $\begin{array}{l}\text { Cachexia } \\
\text { Fever }\end{array}$ & Liver insufficiency & GC & Recovered & {$[16]$} \\
\hline $77 / \mathrm{m}$ & $\begin{array}{c}\text { Fever } \\
\text { Splenic abscess }\end{array}$ & Diabetes & PC & Expired & {$[17]$} \\
\hline $78 / f$ & $\begin{array}{c}\text { Ascites } \\
\text { Bacteremia }\end{array}$ & Chronic liver disease & $\mathrm{CC}$ & Recovered & {$[12]$} \\
\hline $54 / f$ & $\begin{array}{l}\text { Bacteremia } \\
\text { Cellulitis }\end{array}$ & No & $M L$ & Expired & {$[5]$} \\
\hline $36 / \mathrm{m}$ & Cellulitis & Diabetes & SCPC & Expired & Reported case \\
\hline
\end{tabular}

MM, multiple myeloma; CLL, chronic lymphocytic leukemia; NSCLC, non-small-cell lung carcinoma; GC, gastric cancer; PC pancreatic cancer; CC, cervix carcinoma; ML, myeloid leukemia; SCPC, squamous-cell penis carcinoma. 
The case reported shows that non $\mathrm{O} 1-V$. cholerae may produce wound infections in cancer patients with infrequent clinical manifestations. In conventional mediums Vibrio spp. can easily remain undetected especially when polymicrobial infections occur. Consequently, Vibrio spp. should be considered in the differential diagnosis of any SSTI in immunocompromised patients, principally those occurring after seafood ingestion or contact with salt or estuary water. Thus, in these cases, physicians should alert the microbiology laboratory to add selective and enriched culture mediums in addition to routine media.

\section{Consent}

Written informed consent was obtained from the patient for publication of this case report and accompanying images. A copy of the written consent is available for review by the Editor-in-Chief of this journal.

\section{Competing interests}

The authors declare that they have no competing interests.

\section{Authors' contributions}

AA and MP carried out the microbiological assays and drafted the manuscript. JY and JdP participated in clinical infectious disease's diagnosis and treatment. EGT carried out inguinal debridement. JPG participated in the chemotherapy. JL participated in its design and coordination. All authors read and approved the final manuscript.

\section{References}

I. Ko WC, Chuang YC, Huang GC, Hsu SY: Infections due to nonOI Vibrio cholerae in southern Taiwan: predominance in cirrhotic patients. Clin Infect Dis 1998, 27:774-780.

2. Fernandez JM, Serrano M, De Arriba JJ, Sanchez MV, Escribano E, Ferreras P: Bacteremic cellulitis caused by Non-0I, Non-0I39 Vibrio cholerae: report of a case in a patient with hemochromatosis. Diagn Microbiol Infect Dis 2000, 37:77-80.

3. Levine WC, Griffin PM: Vibrio infections on the Gulf Coast: results of first year of regional surveillance. Gulf Coast Vibrio Working Group. J Infect Dis 1993, 167:479-483.

4. Farina C, Gnecchi F, Luzzi I, Vailati F: Vibrio cholerae $\mathbf{O 2}$ as a cause of a skin lesion in a tourist returning from Tunisia. J Travel Med 2000, 7:92-94.

5. Choi SM, Lee DG, Kim MS, Park YH, Kim YJ, Lee S, Kim HJ, Choi JH, Yoo JH, Kim DW, et al.: Bacteremic cellulitis caused by non-OI, non-OI39 Vibrio cholerae in a patient following hematopoietic stem cell transplantation. Bone Marrow Transplant 2003, 31:1 | $81-1182$.

6. NCCLS: Performance standards for antimicrobial susceptibility testing. MIC Interpretative Standards for V.cholerae. 2007: 133 .

7. Stevens DL, Bisno AL, Chambers HF, Everett ED, Dellinger P, Goldstein EJ, Gorbach SL, Hirschmann JV, Kaplan EL, Montoya JG, Wade JC: Practice guidelines for the diagnosis and management of skin and soft-tissue infections. Clin Infect Dis 2005, 4I : | 373- | 406.

8. Chang-Chien CH, Ding HT, Liu C, Yang CS: Vibrio infection associated with finning injury of the hand. Injury 2007, 38:6 |4-6/8.

9. Oliver JD: Wound infections caused by Vibrio vulnificus and other marine bacteria. Epidemiol Infect 2005, 133:383-391.

10. Howard R, Brennaman B, Lieb S: Soft tissue infections in Florida due to marine vibrio bacteria. J Fla Med Assoc 1986, 73:29-34.

II. Berghmans T, Crokaert F, Sculier JP: Vibrio cholerae bacteremia in a neutropenic patient with non-small-cell lung carcinoma. Eur J Clin Microbiol Infect Dis 2002, 2 I:676-678.
12. Calduch Broseta JV, Segarra Soria MM, Colomina Aviles J, Llorca Ferrandiz C, Pascual Perez R: [Septicemia caused by Vibrio cholerae non-0 I in immunocompromised patient]. An Med Interna 2003, 20:630-632.

13. Shelton CH 3rd, Martino RL, Ramsey KM: Recurrent non-0:I Vibrio cholerae bacteremia in a patient with multiple myeloma. Cancer 1993, 72:105-107.

14. Siegel MI, Rogers Al: Fatal non-0 I Vibrio cholerae septicemia in chronic lymphocytic leukemia. Gastroenterology 1982, 83: I|30-I|3|.

15. Lin CJ, Chiu CT, Lin DY, Sheen IS, Lien JM: Non-OI Vibrio cholerae bacteremia in patients with cirrhosis: 5-yr experience from a single medical center. Am J Gastroenterol 1996, 9 I:336-340.

16. Suk JH, Lee NY, Lee JH, Oh WS, Peck KR, Song JH: Vibrio cholerae non-OI, non-OI39 isolated from pleural effusion following total gastrectomy. J Korean Med Sci 2006, 2 I:944-945.

17. Cavuoti D, Fogli M, Quinton R, Gander RM, Southern PM: Splenic abscess with Vibrio cholerae masking pancreatic cancer. Diagn Microbiol Infect Dis 2002, 43:3 II-3I3.
Publish with Bio Med Central and every scientist can read your work free of charge

"BioMed Central will be the most significant development for disseminating the results of biomedical research in our lifetime. "

Sir Paul Nurse, Cancer Research UK

Your research papers will be:

- available free of charge to the entire biomedical community

- peer reviewed and published immediately upon acceptance

- cited in PubMed and archived on PubMed Central

- yours - you keep the copyright

Submit your manuscript here:

http://www.biomedcentral.com/info/publishing_adv.asp
BioMedcentral 